\title{
Is the Greek debt sustainable? Analyzing three different scenarios for the forthcoming period 2018-2022
}

Emmanouil M. L. Economou*, Nicholas Kyriazis

Department of Economics, University of Thessaly, Volos, Greece

Received December 13 2017; Accepted March 192018

Abstract: In this paper, we attempt to estimate the development of the Greek public debt for the period 2018-2022. In order to achieve this, we analyze three different fiscal scenarios that are based on the official data available, together with our estimations that are based on a specific conceptual framework that we develop. The three scenarios are based on a different mixture of Gross domestic product (GDP) growth rates and budgetary surpluses of GDP. The analysis concludes that the numerical outcome is almost the same in all three case scenarios. However, the third scenario is the best since it leads to higher growth, GDP, and less austerity measures, and thus making public debt sustainable in the long run. The third scenario also provides the best combination of the trade-off between austerity and growth. We conclude by discussing some policy measures.

Keywords: Greek Public Debt • Debt Development • Three Fiscal and Growth Policy Scenarios

JEL Classification: $H 21 \cdot H 50 \cdot H 62 \cdot H 63 \bullet P 16$

\section{Introduction}

Greece's last standing crisis of 2010-2017 has raised considerable interest of analysis of various issues that are the causes of the crisis. The discussion regarding the sustainability of Greece's public debt is ongoing. Greece has signed up till now three memoranda, with the third ended in August 2018, linked to an indirect alleviation of Greek debt although, for political reasons, it will not be called a memorandum. Thus, the issue of the sustainability of Greece's public debt is an open question.

The paper is organized as follows: in Section 2, we analyze in brief how the Greek debt crisis evolved before and during the 2010-2017 economic crisis by highlighting certain critical points that resulted in the low positive effect of the three Memoranda bailout packages (memorandum of understanding, MoU's) on the Greek economy in terms of economic restructuring and economic recovery and growth. Section 3 analyzes the structural and institutional inefficiencies of the Greek economy by focusing on the basic findings of The Economic Freedom Indicators as given by the Fraser Institute and the Heritage Foundation. Section 4 focuses on our main argumentation, the analysis of three alternative scenarios concerning the development of the Greek public debt during the 2018-2022 period.

The three scenarios are based on a different mixture of Gross domestic product (GDP) growth rates and budgetary surpluses to GDP that we analyze 
separately for each of the three scenarios. For the first scenario, we assume a GDP growth rate of $2.5 \%$ and a budgetary surplus equal to $3.5 \%$ of GDP; for the second scenario, we assume a growth rate of $3.0 \%$ and a budgetary surplus of $2.5 \%$ of GDP; and for the third scenario, we assume a growth rate of as high as $3.5 \%$ and a budgetary surplus of $1.5 \%$ of GDP. The main hypothesis in the three scenarios is that there is a trade-off between surpluses and growth. Higher surpluses necessitate more austerity measures (higher taxes, cuts in expenditure, reducing growth, while lower surpluses are growth promoting).

This is linked to past experience of the memoranda. Up to now, austerity measures have resulted in a 7-year period of recession, with a cumulative loss of $26 \%$ of GDP, a current rate (October 2017) of $20.6 \%$ unemployment, according to Eurostat, ${ }^{1}$ and a drop of more than $40 \%$ in available income. Furthermore, International Monetary Fund (IMF) forecasts as to growth proved wrong, recession was much deeper and long-lasting, due to a wrong specification of the fiscal (negative) multiplier. This led the director of the IMF, Mrs. Christine Lagarde, and the chief economist, O. Blanchard, to apologize publicly for their mistake. Finally, in Section 5, we offer a comparison and a commentary as to the results concerning the three scenarios, whereas in Section 6 the analysis concludes with some policy proposals.

\section{The reasons that lay behind the excessive rise of the Greek public debt}

In this section, we raise some issues as to why the Greek economy failed to achieve better macroeconomic outcomes during the 2010-2017 economic period. This is important so as to make a cautious and reliable overall report of the Greek economy and to detect the mistakes and inconsistencies that occurred, so as to provide the most suitable institutional instruments toward better macroeconomic outcomes in the near future. What is imperative is that the Greek economy must achieve a stable period of growth rates and public surpluses to gradually shorten the exorbitant level of the Public Debt (180\% of the GDP for 2017).

So far, various authors have voiced their criticism concerning the reasons that lay behind the Greek economic crisis. Among others, Stergiou (2015b) analyzed the "schizophrenic" attitude of many Greeks toward the

1 See http://ec.europa.eu/eurostat/statistics-explained/index.php/Un employment_statistics.
European Union (EU), which combines elements of Euroscepticism with a striving to be accepted as "equal" partners. He further criticized the role of political and economic elites in building a "client" state that he sees as the main cause of Greece's bankruptcy (Stergiou 2015a).

Kotzias (2016), ${ }^{2}$ in a Marxist interpretation and analysis, criticized that the EU has been transformed into an imperium, with Berlin as the "New Rome", and member states in the periphery, such as Greece, as quasi colonies. According to him, the EU no longer consists of equal members, is no longer democratic, and the European Parliament is excluded from decision-making concerning critical issues such as, for example, state debt and memoranda for Greece, Cyprus, Portugal, and Ireland. The EU is characterized by a new "triangle" of international capital markets, the EU bureaucracy, and Germany. He also criticized indirectly the tax policy of Greece's governments and his colleague Tsakalotos, the Finance Minister, for having increased property taxation eight times, leading to "overtaxation" (Uebersteuerung, pp. 39-40). He further accuses Germany of "economic racism" against the memoranda states, which resulted in their being transformed into "debt colonies" (pp. 46 and 53).

Markantonatou (2016) analyzed the austerity measures of the memoranda and concluded that the Fiscal Pact of the EMU leads to the depoliticization of fiscal policy and thus to a transfer of member states' fiscal performance to the ECJ rather than to national or the European Parliament. This further increases the democratic deficit of the EU/EMU. Giannitsis (2015) analyzed the development and the causes of Greek debt. He concluded that the main causes of its steep increase were as follows: i) tax evasion linked to a shadow economy and the client state, ii) "easy social policies" based on "cheap" money through the increased debt of the state, iii) "easy" growth policy measures that favored increased consumption both by the state and the private sector due to low interest rates after the introduction of the euro, instead of increased investment.

Spanou (2015) analyzed the reforms of public administration before and during the crisis. She concluded that while some success has been achieved, mainly in reducing the number of employees and the cost, in other aspects the reforms have failed, as in reducing bureaucracy, increasing mutual trust between the administration and citizens, and increasing efficiency through incentives. The main reason for the failure was that reforms were undertaken mainly under the criterion of cost reduction and not under the criterion of

$2 \mathrm{He}$ is Greece's Foreign Affairs Minister since January 2015. 
reorganization according to goals and efficiency. This resulted in "a devil's circle of loss of morale, deception, and uncertainty, which deteriorated the functioning conditions of the administration" (p. 427).

Karkatsoulis (2015) analyzed the tax administration and its problems, as continuing corruption, lack of transparency, fluidity of laws (the tax laws change or are amended about three times per year, and because of their imprecise formulation need explanatory notes, 196 during 2010, the first year of the crisis, and more than 700 in 2014), etc. For example, in 2009, a company had to make eight different payments for eight different taxes, requiring 234 hours of work (p. 433). He criticized the troika and the memoranda of implementing "show case" reforms that do not touch or ameliorate the problems of citizens and enterprises, therefore, not making Greece a favorable place for FDI. As we show further on with some examples, the situation seems to be worsening. Citizens and enterprises who bear the cost of failed reforms perceive the system not only as exceedingly bureaucratic and inefficient but also as unjust.

Dullien and Schwarzer (2015) analyzed the response of the EU to the Greek crisis. They criticized the measures undertaken because the EU-IMF did not make a clear distinction as to the causes of the crisis, confusing liquidity with solvency problems. They further discussed various alternatives to face future problems, such as the issue of Eurobonds, distinguishing between "blue" (or Eurobonds) which would cover only debt of up to $60 \%$ of GDP and "red" bonds (national bonds) that would cover debt over $60 \%$. Red bonds would presumably carry a higher rate of interest and this would, again presumably, make states more cautious in issuing excessive debt and more financially disciplined. They further argued that the "haircut" of 2012 was not very successful because, while not decreasing debt substantially, it created new problems such as the insolvency of pension funds, the need to recapitalize (three times) Greek banks, coupled with a mass destruction of property rights of old and new shareholders. They considered that the Greek strategy was wrong, burdening the Greek economy and its citizens with excessive costs, the reason being that alternative strategies might destroy the EMU. So, they conclude that the memoranda were not so much introduced to save Greece but mainly to safeguard the EMU.

From this point, we provide our own (in addition to the above) interpretation as far as the Greek economic crisis is concerned. From the 50 s till the mid-70s, Greece achieved a high GDP growth for an extended period of time, which was accompanied by low unemployment rates and a low public debt. The Greek economy grew by an average of $7.7 \%$, being second in the world only to West Germany and Japan. Characteristically, in the early 80s, Greece's Public Debt was approximately $22 \%$ of GDP (Fotopoulos 1992; Maddison 1995; Nelson et al. 2011; Alogoskoufis 2013; Kalyvas 2015). Then, Greek politicians of both main parties, which alternated in heading the government between 1974 and afterward, tried to satisfy the demands of their political clients by increasing wages and salaries and increasing employment in the public sector and by introducing relatively high minimum wages in the private sector. This policy lasted for the entire period 1980-2010.

Political parties tried to satisfy the demands of their political clients: i) by increasing wages in both the private and the public sectors and by performing excessive appointments of civil servants in the public sector (characterized by very poor efficiency), ii) by the excessive rise in taxation of private companies, iii) by parasitic trade union actions that were linked to opportunistic behavior by their leaders (many strikes, etc.). At the same time, iv) there was strong competition from some industrial giants from other EEC countries. Thus (due to ii and iii), the Greek industrial base was under a process of gradual disorganization that led to a loss of competiveness, and v) many high-ranking political officials were involved in corruption scandals, insofar as public-sector procurement was concerned. Furthermore, vi) a large portion of Greeks gradually started to adopt a corruptive mentality of excessive and irrational consumption instead of investing and saving. But even more crucial, vii) by not aggressively pushing tax collection or implementing tax reforms, etc. a black economy was allowed to thrive (estimated at about $30-40 \%$ of official GDP).

Greece's membership in the EMU and the adoption of the euro lowered interest rates and inflation compared to previous periods. Inflation in the 1990s had reached, in some years, over $20 \%$ and interest rates on deposits, $18 \%$. Instead of seeing this as an investment opportunity, both the public and private sectors perceived low interest rates as a consumption bonanza. The public sector borrowed to satisfy higher spending (increases in public employer's salaries, waste etc.) and the private sector for extravagant consumption (banks gave loans even for holidays).

Before the crash of the Greek economy in 2010, the Greek statistical service "cooked" public deficit and debt statistics and, surprisingly, the European Statistical Office accepted them as correct. In 2010, the newly elected PASOK socialist government discovered that the actual situation was different. The public deficit, as stated by the previous government as being about 3-4\% of GDP, was actually about $15.6 \%$ (Giannitsis 2015). The situation was out of control, and the government had to ask the EMU for financial help. It was a totally 
unforeseen situation, and the EMU had no instrument to face a debt crisis of one of its members. ${ }^{3}$ Invoking also a lack of expertise in facing debt crises, the EMU asked for assistance from the expert, the IMF, to draft a program for the financial bailout of Greece together with the necessary reforms. This was the first memorandum agreement, followed within 2 years by a second one and a third in the summer of 2015. In total, the EMU member states and the IMF lent Greece 240 billion euros, the biggest financial assistance package in history to a country of just 11 million people and with a GDP in 2010 of 220 billion euros.

In 2012, a "haircut" of 55\% of the Greek debt was imposed on the private sector (Private Sector Involvement, PSI). Greece was followed by memoranda in other states such as Portugal (in a situation somewhat similar to that in Greece), Ireland (banking sector induced, following the toxic products crash in the USA in 2008), and Cyprus (banking sector induced, due to the exposure of its banks to Greek bonds). Ireland managed to emerge from its memorandum in 2014 and achieved high growth rates and falling unemployment. Furthermore, the situation in Portugal and Cyprus after their exit from the memoranda is improving. After 7 years under the memoranda, the situation in Greece is improving very slowly with a further cumulative negative growth of $-0.7 \%$ for $2015-2016$, and a weak growth of $1.4 \%$ followed in 2017.

Greece's problem was twofold: excessive public debt and a trade balance deficit, due to the lack of competitiveness of the Greek economy. As stated earlier, public debt was due to a bloated public sector because of relationships between political parties and governments and their clients. Thus, the memoranda provided for measures to decrease the size of the public sector (one new employee was to be hired for every five retiring) plus additional firing of employees, closure of non-performing and unnecessary public organizations,${ }^{4}$ corporations, etc. streamlining the

3 This is also astonishing in view of the fact that such mechanisms existed in the EMU's predecessor, the European Monetary System, and some countries, such as Italy, did employ them. It was thought that if countries followed the two financial criteria (public deficit less than $3 \%$ of GDP and public debt less than $60 \%$ ) a debt crisis could never arise, making such mechanisms superfluous. For example, the Delors-Moreau group of the European Parliament (1981-1989) which prepared the EMU had made some proposals that the EMU should have a "safety mechanism or, emergency fund", as its predecessor, the European Exchange Rate System had. The proposals were not accepted, being deemed unnecessary and possibly inducing moral hazard.

4 A notorious case was "Agrogi", a public enterprise that employed 285 employees. It was estimated that the total amount of revenues of the company divided to the annual contribution per employee was public sector (e.g., uniting numerous pension funds into fewer to obtain economies of scale) and reduction of salaries. Parallel to the reduction of expenditures, the programs foresaw revenue increases through increases in taxation (VAT, income and corporate tax and from 2012, a tax on property and houses) and an extensive program of privatization of state property (Kyriazis and Economou 2016).

Then, a third bailout agreement was signed in July 2015 between the Greek government, the EU, and the IMF as a consequence of further financial assistance that was necessary for Greece to avoid bankruptcy. According to this third MoU, in 5 years Greece would receive a loan of up to 86 billion euros to be given from 2015 until June 2018. In return, Greece would have to streamline the VAT system and broaden the tax base to increase revenue, reform the pension system, safeguard the full legal independence of the Greek Statistical Office (ELSTAT), automatically cut public spending to achieve primary surpluses, reform justice to accelerate the judicial process, and reduce costs and implement all the OECD requirements.

\section{The structural institutional inefficiencies of the Greek economy: The Economic Freedom Indicators overview}

Although progress has been achieved, many problems remain that inhibit faster growth. For example, Greece's bureaucratic and political record concerning privatizations and private investment is dismal, as the following examples show: the investment project to reallocate the old Athens Hellenicon airport to other uses (hotel, casino) has been delayed because of the Forestry Director of Piraeus and the Central Archaeological Committee although the contract for the project was signed 3 years ago and was approved by Parliament in 2016. Pending the contract for the casino, work is not expected to begin before 2019 .

The Minister of Merchant Marine and Harbours tried to alter the terms of the contract for the privatization of the second part of the Piraeus harbor with the Chinese company COSCO in July 2016 but was dismissed from government after strong protests by the Chinese Ambassador on behalf of his government. The privatization of Asteras Vouliagmenis, a large tourist resort

about 300 euros (an all-time labor productivity record!) whereas, on the other hand "Agrogi" created an annual deficit of EUR 25 million, covered by the state's budget. It took 4 years to close it down. 
near Athens, was delayed excessively due to recourse to the courts for environmental reasons, and the same has happened with a big development project on Crete, belonging to the Toplou monastery. Investment projects by the Emir of Qatar, al Thani (father of the current reigning monarch), in the Ionian Islands have been held up also, pending court decisions because the use of land is not clear. Finally, due to excessive delays, the investment projects were canceled.

Furthermore, the Afantou golf course in Rhodes has been delayed because, after the signing of the privatization contract, the Archaeological Directorate of the island discovered some ancient remains. For example, revenue from privatization in 2016 amounted to 500 million euro, as against a target of 1.3 billion, a shortfall of about $70 \%$. These are only some examples as to why we estimate that growth rates and public revenue from privatizations will be lower than the forecasts. ${ }^{5}$

It seems that Greek bureaucracy and some ministers ignore the well-known Latin dictum Pacta servanda sunt (e.g., treaties, contracts, must be served, meaning fulfilled). Another serious criticism levied against Greece's Memoranda partners is that they have paid insufficient attention to the bureaucratic-legal obstacles that inhibit investment in Greece, focusing on shortterm financial measures. But the improvement of the institutional framework including the "OECD's toolkit" is what, together with lower tax rates on profit, would bring about higher growth rates and thus make debt sustainable. If we take the ranking of Greece according to the World Economic Freedom Indicators, which are annually published by the Heritage Foundation and the Fraser Institute, as an indicator of Greece's attractiveness for FDI, we see Greece's shortcomings. According to the 2017 Index of Economic Freedom, and the Economic Freedom of the World, 2017, Greece ranks as the least attractive country among the EU and the Eurozone member states.

The Index of Economic Freedom (2017) analyzes countries by four main criteria, rule of law, government size, regulatory efficiency, and open markets, each one further analyzed in 12 sub-criteria. According to the overall evaluation, Greece is placed in the 127th position among 180 countries in economic freedoms with the total score of 55.0 out of 100 and is characterized as "mostly unfree". 6

5 Hopefully, some important privatization agreements have already been settled, such as the sale of 14 regional airports in the Aegean Sea to the German company FRAPORT and the sale of the Greek railway TRAINOSE S.A. to the Italian company Ferrovie Dello Stato Italiane S.p.A.

6 See http://www.heritage.org/index/ranking.
Greece has a very low ranking in the rule of law ratio where it only scores $52.5 / 100$ as a whole. In the judicial effectiveness sub-ratio, it scores only 56.1 since the protection of property rights is not strongly enforced and the judiciary is independent, but the court system is extremely slow. The poorest score is related to government integrity, only $41.3 / 100$. This is related to corruption, which remains a problem in Greece because, although tax enforcement has become more stringent in recent years, authorities have largely failed to prosecute tax evasion by economic elites. ${ }^{7}$

Concerning the government size ratio, the Greek economy scores $61.1 / 100$ in the tax burden sub-ratio, $54 / 100$ in government spending, and 58.1/100 concerning fiscal healthiness. These numbers are justified since personal income tax rate has been increased to $42 \%$, the corporate tax rate has been increased from $26 \%$ to $29 \%$ together with social security payments, by enterprises and employees, and this is raised according to the IMF, to $48 \%$, the highest among its members, followed by Sweden, the world's average being $36.3 \%$ and in Cyprus $40.3 \%$. But the reciprocity, what Greek citizens receive in return in state's goods and services, is the lowest among the OECD countries. Simply put, Greeks pay the most to receive the least and this is the greatest failure of the memoranda. The overall tax burden equals $35.9 \%$ of total domestic income. Furthermore, government spending has amounted to $56.2 \%$ of total output (GDP) over the past 3 years and budget deficits have averaged $3.7 \%$ of GDP. Public debt is very high.

Concerning the regulatory efficiency ratio, the Greek economy scores 74.3/100 in business freedom, because sporadic efforts to enhance the business environment have been undermined by red tape and insufficient political commitment. It scores 51/100, in labor freedom because labor regulations are restrictive, and the economy continues to lack labor mobility. This is related to the ongoing Greek debt crisis that requires considerably more progress on planned privatizations of heavily subsidized and loss-making state-owned enterprises across a wide variety of economic sectors. It scores 78.2 in monetary freedom, due to the introduction of capital controls in 2015 (the so-called "Varoufakis effect") which although eased, are still in place at the time of writing.

Finally, concerning the last criterion, the open markets ratio, it achieves $82 / 100$ in trade freedom, since trade is important to Greece's economy and the value of exports and imports taken together equals $60 \%$ of GDP.

7 For tax-evasion in Greece see the recent study of Artavanis et al. (2016). 
It achieves 60 in investment freedom since foreign and domestic investors are generally treated equally, but bureaucratic barriers may discourage investment and only 40/100 in financial freedom since nonperforming loans are about $50 \%$ of the total banking-sector loans, the second highest level in the euro area.

In order to exhibit the magnitude of the Greek macroeconomic problems, we indicatively refer to the second lowest EU economy's performance as far as Economic Freedoms are concerned, Slovenia, which ranks 97 th out of 180 countries. As it has already been referred, Greece has the lowest ranking in economic freedom indicators (55.0/100) and holds the 127th position. The best performance throughout the EU countries is achieved by Estonia that ranks 6th (75.8/100), followed by Ireland ranking 9th (76.7/100), Luxembourg that ranks 14th $(75.9 / 100)$, the Netherlands and Lithuania, both with a score of $75.8 / 100 .{ }^{8}$ Germany, which is regarded as the "economic steam-engine of the EU," finds itself in the 26th position (73.8/100). Hong Kong holds the 1st position (88.6/100).

According to the Economic Freedom of the World, 2017 Annual Report, of the Fraser Institute for 2017, ${ }^{9}$ Greece again has a very low ranking. It ranks 116th out of 159 countries. In the size of government ratio it achieves $3.4 / 10$, in the legal system and property rights ratio it achieves 6.0 in the sound money 8.3/10 (which is relatively high due to its participation in the Eurozone), in the freedom to trade internationally 7.6/10, and for regulation (open markets, labor and business market regulations) 6.4 (Gwartney et al. 2017: 8,14, 85).

As a final comment, we think that the abovementioned indicators describe quite well a series of characteristic inconsistencies of the Greek economy, which have resulted in a long (and still ongoing) period (2010-2017) of economic recession in the country. It appears that the "remedy", which, in the Greek case, were the three rounds of MoU's bailout packages, proved incapable of solving the economic crisis, in contrast to countries such as Ireland, which exited from its own bailout program at the end of 2013, and Cyprus and Portugal, which exited from their bailout programs in March 2016. ${ }^{10}$

8 It is rather impressive that Estonia and Lithuania, two ex-Soviet countries, have managed to reconfigure their economic institutions so effectively as to manage to achieve the 2nd and the 3rd highest positions among the EU/Eurozone countries. The UK scores $76.4 / 100$, ranking it 12 th but it should no longer be regarded as an EU member following the Brexit decision of 23 June 2016.

9 See https://www.fraserinstitute.org/sites/default/files/economic-freedom-of-the-world-2017.pdf.

10 See https://www.theguardian.com/business/2013/dec/13/irelandfirst-country-exit-eurozone-bailout andhttp://www.cnbc.com/2016/ 03/08/that-was-quick-cyprus-exits-bailout-wit h-cash-to-spare.html.

\section{The three alternative scenarios concerning the development of the Greek public debt during the 2018-2022 period}

In this section, we present three alternative scenarios regarding the development of Greece's public debt for the period 2018-2022. The first is based on the following assumptions: a budget surplus of $3.5 \%$ of GDP each year, growth rates of $2.5 \%$, interest rates on debt constant at $1 \%$ per year, and revenue from privatizations, 2 billion euros each year.

The budget surplus of $3.5 \%$ is the one agreed on under the Third Memorandum (MoU). In order to achieve this, additional measures have to be adopted as, for example, further tax increases (lowering of the tax-exempt income for public sector employees) cuts in pensions, etc. ${ }^{11}$ But these measures reduce available incomes and thus demand consumption and savings, and, at the end, growth rates. Therefore, we assume a growth rate of $2.5 \%$ per year over the period, which is lower than the optimistic rate of about $3.5-4 \%$ per year foreseen in the MoU for the period. We must also underline that up till now, all official predictions of the EU and IMF were widely off the mark, as stated before. ${ }^{12}$

In addition, we must not forget that while GDP fell cumulatively by $26 \%$ during 2009-2016 from its peak of 2008 , available incomes fell, on average, by more than $40 \%$ due to very high tax increases and payments for pensions. The VAT was increased to $23 \%$ and tax rate on profits to $29 \%$ (35\% for companies listed in the Athens Stock Exchange) compared to $10-12 \%$ in Cyprus, Bulgaria, and Ireland. Furthermore, there was an introduction of high property taxes and also cuts in the expenses that can be deducted from income (e.g., medical expenses). Under the new law for insurance

11 The tax-exempt income applies to public sector employees, pensioners etc. but not to the self-employed, who are taxed from the first euro earned! This is a particularity of the Greek tax system which is contrary to the principle of equality. The argument in favor of this is that self-employed persons (lawyers, engineers, doctors etc.) are presumed to be dishonest in their tax declarations, able to hide income, and thus not deserving tax exemptions, like public sector employees who cannot hide their incomes. This again goes against the general principle of presumed innocence. The state presumes that all self-employed are guilty of tax evasion, because its administration has been unable to implement an efficient tax system that would be able to find out the real tax evaders.

12 See http://www.keeptalkinggreece.com/2016/04/11/imf-greecesprogram-lagarde-admits-mistakes-in-fiscal-multipliers-no-consideration-of-human-factor-elections/. For example, the target of growth rate set in the budget for 2017 was $2.7 \%$, the actual one being $1.4 \%$. Target for 2018 is $2.3 \%$ but most independent estimates (and the IMF) reduce it to $2 \%$. 
payments implemented in 2017, self-employed persons have to pay three times what they paid up to 2016 , which, in addition to taxes, brings the total charge on their incomes to $90 \%$ ! It is clear that such a situation is not sustainable and will lead to the closure of many self-employed entities and an increase in black market transactions. This is why the government is accused of tax piracy. Already, during the first 2 months of 2016, 100,000 self-employed have closed their businesses. In April 2018, the Supreme Court of Administration ruled the pension law as being unconstitutional, so that it will have to be amended.

Further, we assume 2 billion euros per year from privatizations, which is used for the reduction of debt. We believe that this is a realistic assumption, being lower than optimistic official predictions. Over the past years, revenue from privatization never exceeded this sum and the government's and bureaucracy's attitude, being as it is inimical to privatizations (MoU obligations notwithstanding), we believe that our assumption is realistic. Finally, we assume that the alleviation measures of Greece's debt will lead to stable interest rates of $1 \%$, as against today's variable rates of interest.

Taking into account that Greece's outstanding debt in 2017 was about 320 billion euros, ${ }^{13}$ this means that interest payments per year for our forecast period amount to 3.2 billion euros. Under these assumptions, we calculate GDP and debt development for our first scenario, given in Table 1.

In Table 1, we estimate Greek GDP growth for the period 2018-2022 based on the first scenario (GDP growth rates of as high as $2.5 \%$ and budgetary surplus equal to $3.5 \%$ of GDP). In order to support such an analysis with reliable statistical data, we use reliable information concerning the Greek GDP in absolute numbers for the recent 2016-2017 period. For the entire 2010-2016 period of the crisis, the Greek economy suffered negative growth rates (except in 2014). Greece's growth rate for 2017 was $1.4 \%$ so that GDP for 2017 is 178 billion euros.

Table 1 estimates the evolution of the Greek GDP and needs a further explanation: row 2 offers an estimation as to how the GDP will grow during the 2018-2022 period by assuming that the Greek economy will achieve stable growth rates of $2.5 \%$, instead of achieving $3.5 \%$ since we consider this prerequisite of the Third Memorandum as too optimistic to be true. Row 3 satisfies the prerequisite of budget surpluses of $3.5 \%$ of the GDP as agreed in the MoU. Thus, in row 2 the aggregate sum of each year's GDP increase is multiplied by $3.5 \%$, and by this, the annual budgetary surplus is estimated.

Row 4 calculates interest payments: it assumes constant interest payments of about $1 \%$ that the Greek government has to fulfill concerning its international lenders. ${ }^{14}$ This very low amount concerning interest payment is related to the assistance of the European institutions to Greece. Otherwise, if Greece returns to the open market and finances part of today's debt held by the official sector (IMF, EU, ESM, and ECB) and by the private sector (substitution of OSI by PSI) then, presumably, Greece will have to pay higher interest rates, due to its exorbitant public debt, which will again increase interest payments. Greece issued a new bond at the beginning of 2018 at $3.5 \%$, which now trades at $4 \%$, a difference to our base calculation. Simply put, if 20 billion of "expensive" open market bonds are satisfied from

\begin{tabular}{|c|c|c|c|c|c|}
\hline Year & 2018 & 2019 & 2020 & 2021 & 2022 \\
\hline $\begin{array}{l}\text { Gross domestic product } \\
\text { (GDP; } 2.5 \% \text { growth rate) }\end{array}$ & $\begin{array}{l}178.43+178.43 \\
\cdot 2.5 \%=182.89\end{array}$ & $\begin{array}{l}182.89+182.89 \\
\cdot 2.5 \%=187.46\end{array}$ & $\begin{array}{l}187.46+187.46 \\
\cdot 2.5 \%=192.14\end{array}$ & $\begin{array}{c}192.14+192.14 \\
\cdot 2.5 \%=196.94\end{array}$ & $\begin{array}{c}196.94+196.94 \\
\cdot 2.5 \% 201.86\end{array}$ \\
\hline $\begin{array}{l}\text { Budgetary surplus }(3.5 \% \text { of } \\
\text { GDP) }\end{array}$ & $\begin{array}{l}182.89 \cdot 3.5 \% \\
=6.4\end{array}$ & $\begin{array}{l}187.46 \cdot 3.5 \% \\
\quad=6.56\end{array}$ & $\begin{array}{l}192.14 \cdot 3.5 \% \\
=6.72\end{array}$ & $\begin{array}{l}196.94 \cdot 3.5 \% \\
=6.89\end{array}$ & $\begin{array}{l}201.86 \cdot 3.5 \% \\
\quad=7.06\end{array}$ \\
\hline Interest payments & $320 \cdot 1 \%=3.20$ & $314.8 \cdot 1 \%=3.14$ & $311.28 \cdot 1 \%=3.11$ & $305.67 \cdot 1 \%=3.05$ & $299.83 \cdot 1 \%=2.99$ \\
\hline Privatization revenues & 2.0 & 2.0 & 2.0 & 2.0 & 2.0 \\
\hline Capital payment due to surplus & $6.4-3.2=3.2$ & $6.56-3.14=3.42$ & $6.72-3.11=3.61$ & $6.89-3.05=3.84$ & $7.06-2.99=4.07$ \\
\hline Total capital payments & $3.2+2.0=5.2$ & $3.42+2.0=5.42$ & $3.61+2.0=5.61$ & $3.84+2.0=5.84$ & $4.07+2.0=6.07$ \\
\hline $\begin{array}{l}\text { Outstanding Public Debt } \\
\text { (absolute numbers) }\end{array}$ & $\begin{array}{c}320.0-5.2 \\
=314.8\end{array}$ & $\begin{array}{c}314.8-5.42 \\
=309.38\end{array}$ & $\begin{array}{l}309.38-5.61 \\
=303.77\end{array}$ & $\begin{array}{l}305.67-5.84 \\
=299.83\end{array}$ & $\begin{array}{l}299.83-6.07 \\
=293.76\end{array}$ \\
\hline Debt/GDP ratio (\%) & $\begin{array}{c}314.8 / 182.89 \\
=172.12\end{array}$ & $\begin{array}{c}309.38 / 187.46 \\
=165.03\end{array}$ & $\begin{array}{c}305.67 / 192.14 \\
=158.09\end{array}$ & $\begin{array}{c}299.83 / 196.94 \\
=152.24\end{array}$ & $\begin{array}{c}293.76 / 201.86 \\
=145.5\end{array}$ \\
\hline
\end{tabular}

Table 1. Estimations of the development of the Greek public debt during the 2018-2022 period based on the First Scenario

13 See https://www.usnews.com/news/business/articles/2017-06-14/ greek-pm-renews-call-for-lenders-to-tackle-greeces-debt.
14 See https://www.esm.europa.eu/publications/how-european-debtrelief-benefits-greece. 


\begin{tabular}{|c|c|c|c|c|c|}
\hline Year & 2018 & 2019 & 2020 & 2021 & 2022 \\
\hline $\begin{array}{l}\text { Gross domestic product } \\
\text { (GDP, 3.0\% growth rate) }\end{array}$ & $\begin{array}{l}178.43+178.43 \\
3.0 \%=183.78\end{array}$ & $\begin{array}{l}183.78+183.78 \\
\cdot 3.0 \%=189.29\end{array}$ & $\begin{array}{l}189.29+189.29 \\
3.0 \%=194.96\end{array}$ & $\begin{array}{l}193.6+193.6 \\
3.0 \%=200.80\end{array}$ & $\begin{array}{l}200.80+200.8 \\
3.0 \%=206.82\end{array}$ \\
\hline $\begin{array}{l}\text { Budgetary surplus ( } 2.5 \% \\
\text { of GDP) }\end{array}$ & $\begin{array}{l}183.78 \cdot 2.5 \% \\
\quad=4.59\end{array}$ & $\begin{array}{l}189.29 \cdot 2.5 \% \\
\quad=4.73\end{array}$ & $\begin{array}{l}194.96 \cdot 2.5 \% \\
=4.874\end{array}$ & $\begin{array}{l}200.8 \cdot 2.5 \% \\
\quad=5.02\end{array}$ & $\begin{array}{l}206.82 \cdot 2.5 \% \\
\quad=5.17\end{array}$ \\
\hline Interest payments & $320.0 \cdot 1 \%=3.2$ & $316.61 \cdot 1 \%=3.16$ & $313.04 \cdot 1 \%=3.13$ & $309.3 \cdot 1 \%=3.09$ & $305.37 \cdot 1 \%=3.05$ \\
\hline Privatization revenues & 2.0 & 2.0 & 2.0 & 2.0 & 2.0 \\
\hline $\begin{array}{l}\text { Capital payment due to } \\
\text { surplus }\end{array}$ & $4.59-3.2=1.39$ & $4.73-3.16=1.57$ & $4.87-3.13=1.74$ & $5.02-3.09=1.93$ & $5.17-3.05=2.0$ \\
\hline Total capital payments & $1.39+2.0=3.39$ & $1.57+2.0=3.57$ & $1.74+2.0=3.74$ & $1.93+2.0=3.93$ & $2.11+2.0=4.11$ \\
\hline $\begin{array}{l}\text { Outstanding Public Debt } \\
\text { (absolute numbers) }\end{array}$ & $\begin{array}{c}320.0-3.39 \\
=316.61\end{array}$ & $\begin{array}{l}316.61-3.57 \\
=313.04\end{array}$ & $\begin{array}{l}313.04-3.74 \\
=309.3\end{array}$ & $\begin{array}{c}309.3-3.93 \\
=305.37\end{array}$ & $\begin{array}{l}305.37-4.11 \\
=301.26\end{array}$ \\
\hline Debt/GDP ratio (\%) & $\begin{array}{l}316.61 / 183.78 \\
\quad=172.27\end{array}$ & $\begin{array}{l}\text { 313. } 04 / 189.290 \\
=165.37\end{array}$ & $\begin{array}{l}309.3 / 194.96 \\
=158.64\end{array}$ & $\begin{array}{l}305.37 / 200.80 \\
\quad=152.07\end{array}$ & $\begin{array}{l}\text { 301. } 26 / 206.82 \\
\quad=145.66\end{array}$ \\
\hline
\end{tabular}

Table 2. Estimations of the development of the Greek public debt during the 2018-2022 period based on the Second Scenario

"cheap" EU-ESM debt, the additional charge for interest payments is 600 Mio per year.

Furthermore, we also assume that the Greek public debt, which was analogous to 321 billion euros in 2016, will be approximately 320 billion euros in 2017 , according to estimations (see footnote 11). This means that the interest rate payments will be 3.2 billion euros for 2018 ( 320 billion euros: $1 \%=3.2$ billion euros, see line 4 , column 2 in Table 1). Thus, we calculate interest payments to be $1 \%$, a constant percentage per year to facilitate the forecast. Actually, since we assume that each year's outstanding debt is being reduced due to payments, this sum becomes slightly less over the years.

In row 5, we hypothesize that the Greek policymakers will manage to handle more efficiently the issue of earning revenues by privatizations for the entire period 2018-2022, and for reasons of ease, we estimate steady revenues as high as 2 billion euros. Row 6 presents the calculation of the sum, which is the difference between budgetary surplus (row 3 ) and the interest payments (row 4). Row 7 presents the calculation of the sum of privatization revenue (row 5 ) and capital payments due to surplus (row 6). Row 8 calculates the previous year's debt minus capital repayments (row 8 minus row 7). This means that row 8 actually shows the calculation of each year's total Public Debt as it derives from the previous calculations. Finally, row 9 shows the calculation of the total Public Debt in each year as a percentage of this year's GDP. The results of this First Scenario show that with a stable growth rate of $2.5 \%$ for the 5 -year period, 2018-2022 period, Greece will manage to significantly reduce its debt from about $180 \%$ in 2016 to $145.5 \%$ in 2022. This will definitely be a real positive reconfiguration of the public debt macroeconomic ratio because it will further raise serious expectations concerning the viability of the Greek public debt for the next 2023-2030 period.

Scenario 1 proves that if Greece manages to achieve sustainable growth rates for the period 2018-2022, and afterward, the debt will be further reduced and at some time (possibly till 2030) may reach the $125 \%$ level. This level is regarded as critical for an economy, to be characterized as "sustainable", according to the European Commission's interpretation. ${ }^{15}$ The critical point here is if, in reality, an economy, in as serious a crisis as the Greek one during the 2010-2017 period, can manage to achieve stable growth rates for an extended period during 2018-2022 and later. In the concluding section, we offer some proposals as to how this scenario could be achieved in practice.

We now turn to the second scenario, given in Table 2, where we change two basic assumptions: first we assume a lower agreed budgetary surplus of $2.5 \%$ (instead of $3.5 \%$ ), which seems to be more realistic and sustainable over the period, also according to the IMF. Second, we assume that this has a positive outcome on growth rates (less recessionary-restrictiveausterity measures necessary), which increase from $2.5 \%$ to a still conservative estimate of $3 \%$. By performing the required estimations based on the same methodology that was used in Table 1, we reach a 145.66 Debt/GDP ratio, which is slightly higher than Scenario 1 (145.5).

We finally proceed to the third debt reduction scenario, which we call "the IMF Scenario", since we assume here a budgetary surplus of $1.5 \%$ and a GDP growth rate

15 See https://ec.europa.eu/info/sites/info/files/ecfin_debt_sustainability_analysis_en.pdf and https://ec.europa.eu/info/sites/info/files/ ecfin_presentation_4th_review_2nd_programme_brussels_en.pdf. 
of $3.5 \%$ over the period, which is what the IMF believes to be sustainable in the long run. We further assume, as before, a trade-off between surpluses and growth, so that in this scenario lower surpluses induce lower recessionary effects and thus higher growth rates of $3.5 \%$. As we did also in the second scenario, we retain the assumption of privatization revenues of 2 billion euros per year and fixed interest rates of $1 \%$ and present the results in Table 3.

The results show that the third scenario leads to a $146.88 \%$ Debt/GDP ratio, which means that this is the best numerical outcome by comparing the three different scenarios. The third scenario should be considered the best option because it not only predicts a superior outcome in comparison to the other two scenarios but also leads to higher GDP growth (211 billion euros in 2022), which further means that on a long-term basis the outstanding debt could be serviced easier under it.

\section{Conclusions}

We have presented the abovementioned three scenarios with a different policy mix between budgetary surpluses and growth. Table 4 compares and interprets the outcomes of the three scenarios.

All three scenarios end with almost the same Debt/ GDP ratio, with the third scenario to be only marginally superior to the two previous scenarios, but different GDP's, in the first scenario 201.8 billion, in the second 206.8 billion and 211.89 billion, respectively. The third scenario leads to 10 billion more GDP by the end of the period, with corresponding lower unemployment, and thus it is the preferred one. This means that less austerity (lower surpluses) does not endanger the sustainability of debt but makes it more sustainable in the long run. Moreover, as was already mentioned, the third scenario leads to a higher GDP, which means, further, that on a long-term basis the outstanding debt could be serviced easier.

Another failure of the memoranda programs till now has been their emphasis on short-term financial issues that, although necessary, do not address long-term problems. One that threatens the future of the Greek economy (and pensions in particular) is demographic. After 2010, 450,000 Greeks, mainly young and highly qualified people, have left Greece to find employment

\begin{tabular}{|c|c|c|c|c|c|}
\hline Year & 2018 & 2019 & 2020 & 2021 & 2022 \\
\hline $\begin{array}{l}\text { Gross domestic product } \\
\text { (GDP, 3.5\% growth rate) }\end{array}$ & $\begin{array}{l}178.43+178.43 \\
\cdot 3.5 \%=184.67\end{array}$ & $\begin{array}{l}184.67+184.67 \\
3.5 \%=191.13\end{array}$ & $\begin{array}{l}191.13+191.13 \\
3.5 \%=197.81\end{array}$ & $\begin{array}{l}197.81+197.81 \\
3.5 \%=204.73\end{array}$ & $\begin{array}{l}204.73+204.73 \\
\cdot 3.5 \%=211.89\end{array}$ \\
\hline $\begin{array}{l}\text { Budgetary surplus ( } 1.5 \% \\
\text { of GDP) }\end{array}$ & $\begin{array}{l}184.67 \cdot 1.5 \% \\
=2.77\end{array}$ & $\begin{array}{l}191.13 \cdot 1.5 \% \\
=2.86\end{array}$ & $\begin{array}{l}197.81 \cdot 1.5 \% \\
=2.96\end{array}$ & $\begin{array}{l}204.73 \cdot 1.5 \% \\
\quad=3.07\end{array}$ & $\begin{array}{l}210.4 \cdot 1.5 \% \\
\quad=3.17\end{array}$ \\
\hline Interest payments & $320.0 \cdot 1 \%=3.2$ & $318.5 \cdot 1 \%=3.18$ & $316.82 \cdot 1 \%=3.16$ & $315.2 \cdot 1 \%=3.15$ & $313.28 \cdot 1 \%=3.13$ \\
\hline Privatization revenues & 2.0 & 2.0 & 2.0 & 2.0 & 2.0 \\
\hline $\begin{array}{l}\text { Capital payment due to } \\
\text { surplus }\end{array}$ & $2.77-3.2=-0.5$ & $2.86-3.18=-0.32$ & $2.96-3.16=-0.2$ & $3.07-3.15=-0.08$ & $3.17-3.13=0.04$ \\
\hline Total capital payments & $-0.5+2.0=1.5$ & $-0.32+2.0=1.68$ & $-0.2+2.0=1.8$ & $-0.08+2.0=1.92$ & $0.04+2.0=2.04$ \\
\hline $\begin{array}{l}\text { Outstanding Public Debt } \\
\text { (absolute numbers) }\end{array}$ & $\begin{array}{l}320.0-1.5 \\
=318.5\end{array}$ & $\begin{array}{l}318.5-1.68 \\
=316.82\end{array}$ & $\begin{array}{l}316.82-1.8 \\
=315.02\end{array}$ & $\begin{array}{l}315.2-1.92 \\
=313.28\end{array}$ & $\begin{array}{l}313.28-2.04 \\
=311.24\end{array}$ \\
\hline Debt/GDP ratio (\%) & $\begin{array}{c}318.5 / 184.67 \\
=172.4\end{array}$ & $\begin{array}{c}316.82 / 191.13 \\
=165.7\end{array}$ & $\begin{array}{c}315.02 / 197.81 \\
=159.25\end{array}$ & $\begin{array}{c}313.28 / 204.73 \\
=153.0\end{array}$ & $\begin{array}{c}311.24 / 211.89 \\
=146.88\end{array}$ \\
\hline
\end{tabular}

Table 3. Estimations of the development of the Greek public debt during the 2018-2022 period based on the Third Scenario

\begin{tabular}{|c|c|c|c|c|c|}
\hline Year & 2018 & 2019 & 2020 & 2021 & 2022 \\
\hline First scenario: & \multicolumn{5}{|c|}{ Gross domestic product (GDP; $2.5 \%$ growth rate), budgetary surplus (3.5\% of GDP) } \\
\hline Debt/GDP ratio & $\begin{array}{l}314.8 / 182.89 \\
=172.12\end{array}$ & $\begin{array}{l}309.38 / 187.46 \\
=165.03\end{array}$ & $\begin{array}{c}305.67 / 192.14 \\
=158.09\end{array}$ & $\begin{array}{c}299.83 / 196.94 \\
=152.24\end{array}$ & $\begin{array}{c}293.76 / 201.86 \\
=145.5\end{array}$ \\
\hline Second scenario: & \multicolumn{5}{|c|}{ GDP (3.0\% growth rate), budgetary surplus ( $2.5 \%$ of GDP) } \\
\hline Debt/GDP ratio & $\begin{array}{c}316.61 / 183.78 \\
=172.27\end{array}$ & $\begin{array}{c}313.04 / 189.290 \\
=165.37\end{array}$ & $\begin{array}{l}309.3 / 194.96 \\
=158.64\end{array}$ & $\begin{array}{c}305.37 / 200.80 \\
=152.07\end{array}$ & $\begin{array}{c}301.26 / 206.82 \\
=145.66\end{array}$ \\
\hline Third scenario: & \multicolumn{5}{|c|}{ GDP (3.5\% growth rate), budgetary surplus ( $1.5 \%$ of GDP) } \\
\hline Debt/GDP ratio & $\begin{array}{c}318.5 / 184.67 \\
=172.4\end{array}$ & $\begin{array}{l}316.82 / 191.13 \\
=165.7\end{array}$ & $\begin{array}{c}315.02 / 197.81 \\
=159.25\end{array}$ & $\begin{array}{c}313.28 / 204.73 \\
=153.0\end{array}$ & $\begin{array}{c}311.24 / 211.89 \\
=146.88\end{array}$ \\
\hline
\end{tabular}

Table 4. Comparing and interpreting the three scenario outcomes 
abroad, the reason being that unemployment among $20-30$-year-old is about $50 \%$. This is equal to almost $4 \%$ of the total population and $10 \%$ of the working population,

If they had stayed in Greece, they probably would not have found a job and thus the unemployment rate would have been much higher. As was already mentioned, the unemployment rate for 2017 was $20.6 \%$ according to Eurostat, which hopefully means that it was reduced in comparison to 2016 (23.55\%). ${ }^{16}$ These figures exclude those 450,000 mainly young Greeks who have left Greece. One also has to keep in mind that the unemployment rate was reduced in comparison to the previous years because the mixture of employment tends to part-time jobs instead of full-time jobs. Furthermore, the fertility rate, to keep population stable, is 2.1 children per woman. After 2010, this dropped in Greece to 1.3. If these two trends are not reversed soon, they represent a time bomb in the foundation of the Greek economy and society. The memoranda have nothing to say on this, no measures are provided to reverse the trend.

Other negative trends are the following: GDP has fallen from its peak of 242 billion in 2008 to its present of about 176 billion, middle class citizens from about $50 \%$ has been reduced to $25 \%$ (negative social mobility), share values in the Athens Stock Exchange have lost 90\% of their 2008 high (destruction of property), "red loans" (loans that are not serviced and are in arrears) have reached 106 billion (which is as high as $60.5 \%$ of the 2016 GDP), available incomes have fallen by 57 billion (due to GDP reduction and higher taxation), wealth has fallen by 587 billion representing a net loss of 67.7 euro per family, and housing has lost almost $50 \%$ of its 2008 value (but is still taxed on 2008 values, which the Supreme Court has ruled is a violation of the Constitution, but as of now the government has not changed the valuation basis of the tax). Thus, the application of the memoranda does raise not only economic policy issues but also serious social issues and issues of democracy and the rule of law.

More than 4.3 million Greeks (50\% of those liable to taxation) owe to the fiscal authorities, approximately 106 billion euros (October 2017'7), and this increases by 2 billion unpaid taxes every month, ${ }^{18}$ and thus becoming

16 See https://www.statista.com/statistics/263698/unemployment-ratein-greece/.

17 See https://www.brookings.edu/blog/up-front/2017/10/18/greecesnon-performing-loans-a-source-of-instability-a-prime-obstacle-to-astrong-recovery/.

18 Those owing taxes were only 1 million in 2010. Of taxes certified, only $45 \%$ was being collected in 2016 as against $75 \%$ in 2010 . Thus, the Greek private sector is burdened by a total of 200 billion, which is $114.2 \%$ of GDP in nonperforming loans and unpaid taxes. "hostages" to the fiscal authorities, which have the authority to implement brutal measures such as confiscations etc. Thus, this is not just, or mainly, a fiscal problem but an abuse of democracy and human rights.

Many economists, the IMF, and the Budget Office of the Greek Parliament believe that the $3.5 \%$ surplus is unrealistic in the long run and has negative effects on growth and thus on debt. ${ }^{19}$ Therefore, we think that a policy reorientation toward long-term growth and structural reforms is necessary, which means that the second and the third scenarios we provide with our analysis may be seen as alternative policy proposals for the Greek policy makers, in coordination with EU Institutions and the IMF. The third scenario seems to be the optimal case between the three of them.

As other authors have indicated (Giannitsis 2015), high budget surpluses mean a continuing stress for the Greek economy and, according to Giannitsis, would require unrealistic growth rates of $4 \%$. No benefits of growth would accrue to Greek citizens but only for the payment of debt. This is not a realistic assumption, neither in economic nor in political terms, and we should add, in democratic terms, and are strong disincentives for enterprises and citizens to undertake investment and work effort. Most economists have argued and still argue (and are proven correct by the long recession and only hesitant recovery) that the policy mixture of the memoranda was wrong, with tax increases that were too high and expenditure cuts that were too low. In April 2018, Paul Tomsen, the IMF individual responsible for Europe and initiator of the first memorandum, also stated that tax rates should be reduced and the tax base widened. The fact that high tax rates are growth inhibiting has also been proven by Ireland and Cyprus, whose "red line" during their memoranda" negotiations were that the tax rate on profits $(12.5 \%)$ should not be increased. This was achieved and in 2017 Ireland had a growth rate of $4.7 \%$ and Cyprus 3.6\% as against Greece's 1.4\%, the lowest in the EU.

Another major problem is the political system and the voting rules. Most authors indicate that Greece's political system and the client state that has been established as one of or the major, cause of the 2010 bankruptcy. But the memoranda have not introduced an overall strategy to solve the problem, limiting themselves to partial solutions as, for example, the one person hired to five people retired in the civil service. On the other hand, they still turn a blind eye to attempts of the actual government to build its own client base through

19 Another example of the slowness of the legal system is the Siemens litigation. Siemens is accused (in German and Greek courts) for corruption. The process has just begun in the Greek courts, after 10 years since its introduction! 
the establishment of new public organizations etc., with non-permanent employees.

The problem of political instability also remains so long as the Constitution is not amended. Governments have the option to change the electoral rules, the current government opting for a simple majority rule for the one after the next election. If this is not changed it could make the formation of government coalitions extremely difficult. Also, since the President of the Republic is elected by Parliament, requiring 180 votes out of 300 , if this quota is not achieved in 2020 (when the term of office of the current President expires), anticipated elections will have to be held, as happened in a similar situation in 2014 which led to the January 2015 elections. So, in the long run, economic development in Greece depends, as expected, on political and constitutional change.

Furthermore, economic growth depends on investment and some estimates are that about a 100 billion investment is needed during the next 5 years to achieve the $3.5 \%$ target growth rates. If the environment (illustrated by this indicator) does not ameliorate quickly, it is very doubtful that FDI to Greece will reach the necessary levels, while investments from inland sources (due also to the problems of the banking system) cannot cover the gap. So, the main task of future Greek

\section{References}

Alogoskoufis G., Macroeconomics and politics in the accumulation of Greece's debt: an econometric investigation, 1975-2009, Greece Paper No.68. Hellenic Observatory Papers on Greece and Southern Europe, Hellenic Observatory, European Institute, LSE, 2013. Available at: http://eprints.Ise. ac.uk/50257/1/GreeSE_No68.pdf

Artavanis N., Morse A., Tsoutsoura M., Measuring income tax evasion using bank credit: evidence from Greece, Q J Econ, 131(2), 739-798, 2016.

Dullien S., Schwarzer D. Der Umgang mit Staatsbankrotten im Euroraum: Bislang nur Hilfskonstruktionen, in: Klemm, U.D., Schultheiß, W. (Eds.), Die Krise in Griechenland: Ursprünge, verlauf, Campus Verlag GmbH, Frankfurt am Main, 373-394, 2015.

Fotopoulos T., Economic restructuring and the debt problem: the Greek case, Int Rev Appl Econ, 6(1), 38-64, 1992.

Giannitsis T., Die griechische staatsverschuldung und die Krise, in: Klemm, U.D., Schultheiß, W. (Eds.), Die Krise in Griechenland: Ursprünge, verlauf, Campus Verlag GmbH, Frankfurt am Main, 198-215, 2015. governments and the EU institutions which will still have a function of "increased supervision" 20 will be to implement structural reforms (less bureaucracy, lower tax rates on profits, etc.) to attract more FDI. If not, "The Greek crisis-tragedy will remain a continuing EU and European tax-payer problem". ${ }^{21}$

The Economic Freedom Indicators presented in Section 3 show the main areas of reform: Less government and government expenditure, less bureaucracy, lower taxes on profits, lower contributions for pensions, and faster litigation, ${ }^{22}$ facing efficiently the extensive tax evasion that erodes public revenues and demographic measures. OECD toolkit directives must also be adopted by being combined with the abovementioned proposals. If they are implemented, then Greece may recover quickly and show high growth rates. If not, the future is bleak.

20 As was made clear after the April 2018 Eurogroup and by Greece's Finance Minister Tsakalotos, representatives of the EU institutions will visit Greece four times per year after the expiration of the memoranda.

21 As one anonymous referee concluded!

22 As reported in the February report of the Greek Budget's Office (coordinator Prof. P. Liargovas) in "To Vima" newspaper of 26 February 2017.
Gwartney J., Lawson R., Hall J., Economic freedom of the world 2016 Annual Report. The Fraser Institute, 2016. Available at: http://www.freetheworld. com/2016/economic-freedom-of-the-world2016.pdf

IMF Country Report, Greece 2016 Article IV consultation-press release. Staff report a statement by the executive director for Greece. IMF Country Report Country Report No. 17/40, 2017. Available at: https://www.imf.org/en/Publications/ CR/Issues/2017/02/07/Greece-2017-ArticleIV-Consultation-Press-Release-Staff-Reportand-Statement-by-the- 44630

Kalyvas S.N., Modern Greece. What everyone needs to know. Oxford University Press, Oxford, 2015.

Karkatsoülis P., Die reform der griechischen Steuerverwaltung, in: Klemm, U.D., Schultheiß, W. (Eds.), Die Krise in Griechenland: Ursprünge, verlauf, Campus Verlag GmbH, Frankfurt am Main, 431-447, 2015.

Kotzias N., Ein neuer rahmen für die interpretation der Krise in Südeuropa, in: Agridopoulos A., Papagiannopoulos, I. (Eds.), Griechenland im europäischen 
Kontext: Krise und Krisendiskurse (Staat Souveränität - Nation), Springer VS, 39-66, 2016.

Kyriazis N., Economou E.M.L., The memoranda trap and the near fall of Greece, In Caldwell D. (Ed.), Greece: economic crises and management, Nova Publishers, New York, 75-93, 2016

Maddison A., Monitoring the world economy 1820-1992, OECD Development Centre, Paris, 1995.

Markantonatou M., Griechenland als eine „marktkonforme Demokratie", in: Agridopoulos A., PapagiannopouIos, I. (Eds.), Griechenland im europäischen Kontext: Krise und Krisendiskurse (Staat - Souveränität Nation), Springer VS, 259-274, 2016.

Nelson R.M., Belkin P., Derek M.E., Greece's debt crisis: overview, policy, responses, and Implications. Congressional Research Service, 7-5700, 2011. Available at: https://fas.org/sgp/crs/row/R4 1167.pdf
Spanou K., Auf der Suche nach einer effizienten öffentlichen Verwaltung, in: Klemm, U.D., Schultheiß, W. (Eds.), Die Krise in Griechenland: Ursprünge, verlauf, Campus Verlag GmbH, Frankfurt am Main, 415-430, 2015.

Stergiou A., Staatsverständnis und klientelismus in Griechenland, in: Klemm, U.D., Schultheiß, W. (Eds.), Die Krise in Griechenland: Ursprünge, Verlauf, Folgen, Campus Verlag GmbH, Frankfurt am Main, 111-125, 2015a.

Stergiou A., Griechenland in der Europäischen Union, in: Klemm, U.D., Schultheiß, W., (Eds.), Die Krise in Griechenland: Ursprünge, Verlauf, Folgen, Campus Verlag GmbH, Frankfurt am Main, 111-125, 2015b.

The Index of Economic Freedom, Greece. The Heritage Foundation, 2017. Available at: http://www.heritage.org/index/ranking, http://www.heritage.org/ index/country/greece 